T. Sakhno, Dr. Chemistry, Professor, E-mail: sakhno2001@gmail.com

http://orcid.org/0000-0001-7049-4657

ResearcherID: AAL-4074-2020

Scopus Author ID: 7003968703

Poltava State Agrarian Academy, 1/3 Skovorody Str., Poltava, 36003, Ukraine

A. Semenov, Ph.D., Associate Professor, E-mail: asemen2015@gmail.com http://orcid.org/0000-0003-3184-6925

Poltava University of Economics and Trade, 3, Koval Str., Poltava, 36014, Ukraine

N. Barashkov, Dr. Chemistry, Professor, E-mail: nikolay@microtracers.com https://orcid.org/0000-0003-2494-9248

ResearcherID: AAL-3173-2020

Scopus Author ID: 7003571202

Micro-Tracers, Inc, 1370 Van Dyke Ave, San Francisco, CA, 94124, USA, +380532220680

\title{
ASSESSING THE QUALITY OF HOMOGENEITY OF PET FOOD USING FERROMAGNETIC MICROTRACERS
}

\begin{abstract}
Obtaining highly homogeneous mixtures is an urgent task in many areas of feed production, as it is associated with the need for even distribution of particularly important and valuable components. Manufacturers of animal feed are using several different methods for performing homogeneity studies to check their mixer performance.

This paper is devoted to the use of nontraditional markers such as ferromagnetic Microtracers to evaluate the homogeneity of the final feed. Microtracers have successfully been used in a mixer testing program in the USA since 1985 and in Europe since 2006. They represent a major improvement over traditional analytical procedures for evaluation of mixer performance involving the use of cobalt or manganese salts. The authors described the quantitative results of determination and identification of Microtracers in two sets of 20 samples of pet food manufactured by Kormotech LLC with using a proprietary Rotary Detector procedure developed by Micro-Tracers Inc (San Francisco, California). It was shown that analysis of $150 \mathrm{~g}$ samples at level of Microtracer addition of $20 \mathrm{~g}$ per metric ton of pet food allowed a magnetic retrieval of the number of ferromagnetic particles from 61 to 101 which was sufficient for application of Poisson and Chi-squared statistics. The obtained results from two tests performed with different time of mixing were interpreted in accordance with the requirements of the GMP $+B A 2$ standard. It was determined that mixing within 3 min leads to the marginal mixing with the calculated probability value of $1.12 \%$. The prolonged mixing within 4 min leads to complete mixing with the calculated probability value of 5.93\%. The use of ferromagnetic Microtracers in a mixer testing program is justified for such tasks as comparison of mixers with each other, as well as identifying the changes in the technical characteristics of the mixers and their performance occurring during their exploitation. In addition, using microtracers can quickly determine the quality of the mixing equipment when it is purchased.
\end{abstract}

Keywords: mixing, compound feed, food quality, microtracers, markers, pet food, the Rotary Detector.

Introduction. Formulation of the problem

Despite the rapid growth of the global pet food market, the domestic market demonstrates the untapped potential $[1,2]$. Conducting basic scientific research in the direction of developing new formulations and technologies for the manufacture of finished feeds [3] include the following: studying their usefulness, quality and safety, improving existing and developing new methods for monitoring quality [4]. The results of this basic research are able to contribute to improving competitiveness and increasing the share of domestic producers in the industrial feed market for unproductive animals

An effective method for the production of pet food based on meat and vegetables using poultry offal for meat and bone meal is described in study [5]. The formulation of the combined meat and vegetable pet food developed and optimized by the authors meets the physiological needs of the animal's body and meets the established regulatory requirements.

European law tightens the use of slaughter byproducts, and since 2002, the EU has banned the use of secondary poultry products for animal feed and pet food [6]. The lack of adequate dietary protein is a problem in feeding domestic animals.

The market of pet food today is developing dynamically and its annual growth averages at level of 12$25 \%$ [7]. Such countries as Germany, France, Great Britain, the USA and China are among the most significant producers and importers of pet food. Due to the current political and economic situation in the world, many importers have reduced supply volumes. On the other hand, an increase in the population of domestic animals causes a natural increase in pet food intake. Thus, a favorable situation is currently developing for the development and promotion of new pet food products which consist of numerous important and valuable ingredients.

Obtaining highly homogeneous mixtures of these ingredients is an urgent task in many steps related to the pet food production. Therefore, the manufacturers of these products must have a solid evidence of the high quality of their materials based on accurate dosing and uniform mixing of all components [8].

To our time, there is no single methodology for determining the quality of mixing adopted in Ukraine. The methodology for determining the quality of mixing refers to the international standard [9], the practical ap- 
plication of which is very time-consuming and costly.

It is believed that Ukraine is in 8th place in the TOP 10 fast-growing pet food markets. However, foreign producers dominate the Ukrainian feed market, in particular from countries such as Hungary, Russia, the USA, France and others.

In 2003, the company Kormotech LLC has been founded in Ukraine. Today this company has become the leading domestic producer of pet food, entering the TOP50 of the largest European manufacturers, arranging the export of its products to 18 countries [10]. Kormotech LLC produces its products under the following brands: Optimeal TM, Club 4 Paws TM, Meow TM, Gav TM and Private Cable. Each type of pet food developed by Kormotech's specialists is based on their innovative approach called "IMMUNITY SUPPORT MIX". Implementation of this approach allowed to create a pet food enriched with a number of components necessary to maintain animal immunity. At the same time, the developed rations fully comply with the basic safety criteria of FEDIAF (European Federation of Pet Food Producers) and ISO 22000. Currently Kormotech LLC is interested in the preparation of their facility to the certification audits in accordance with GMP+ FC requirements [9]. One of the important steps in this process includes performing several tests of its mixers according to GMP + BA2 using ferromagnetic Microtracers to assess the quality of mixing pet food products.

In this paper, the authors described the use of safe markers such as ferromagnetic Microtracers for assessing the quality of the feed mixture homogeneity. For preliminary and qualitative results on the determination and identification of Microtracers in the analyzed sample the Mason Jars [11, 12] should be used. To quantify the quality of mixing and assess the level of contamination of feed mixtures, the use of a Rotary Detector is recommended $[13,14]$.

Microtracers ${ }^{\mathrm{TM}}$ have been reported as a tool for evaluating mixer performance and uniformity in feed materials [15-17].

Microtracers F -series consist of iron grit particles colored with food-grade water soluble or water insoluble (lake) food dyes and are designed to be used in premixes and complete feeds. They can be retrieved from feed materials via magnetic separation. The particle count is approximately $25000 / \mathrm{g}$ and the particle size range is 150-300 micron.

When analyzing particle count data, it is standard to assume an underlying Poisson distribution [9,18,19], with the shape and location of the distribution described by a single parameter, $\lambda$. In this study, the focal data are counts of Microtracers particles in individually pet food samples that may or may not have been produced uniformly. If the pet food samples are sufficiently uniform, then repeated items in the production run will reflect a Poisson distribution around a mean value $(\lambda)$ that is the count of tracer particles that were originally added in pet food samples, scaled to mass.

A goodness of fit test such as the Pearson's Chisquare test is an appropriate tool to evaluate Microtracer counts by testing if observed count distribution is significantly different from what may be expected from a truly random Poisson distribution $[13,19]$. The $P$ value result of the Chi-square test estimates the probability that the set of observations were drawn from a uniform population and that the variation observed between pet food samples is solely due to random Poisson variation.

Materials composed of particles with discernible differences in physical properties (e.g., particle size, density, rigidity, or surface properties) have a tendency for segregation of particles $[15,19]$. Uniformity in particle size and limited particle size range are especially critical in limiting segregation. Thus, Microtracers particle size distribution should be comparable to the materials to which it is incorporated to achieve uniform distribution.

This study was undertaken to investigate the potential use of Microtracers $\mathrm{F}$ as a quality control tool to estimate the variability in the process used to manufacture pet food. Variability of test items was evaluated based on distribution of incorporated tracers. If tracers prove to be a useful tool for assessing the uniformity of pet food samples, they may be suitable as a routine quality control tool for laboratory proficiency testing schemes in accordance with ISO 17025 and in the accreditation of organizations providing proficiency testing schemes in accordance with ISO/IEC 17043.

\section{Materials and methods}

The following Base feed materials manufactured by Kormotech have been tested using Microtracers FSeries:

Woof! $!^{\mathrm{TM}}$ - dog food; Meow! ${ }^{\mathrm{TM}}$ - cat food; Club 4 Paws $^{\mathrm{TM}}$ (former 4 Paws Club ${ }^{\mathrm{TM}}$ ) - top quality dog and cat feeds, Optimeal ${ }^{\mathrm{TM}}$ - top quality dog and cat feeds with prebiotics, berries and herbs aimed at enhancing the animal's immunity .

This particular paper includes only data related to the pet food of Optimeal ${ }^{\mathrm{TM}}$ brand.

Two Microtracer F-Series, namely F-Red \#40 and F-Blue \#1 manufactured Micro-Ttracers, Inc. (San Francisco, CA, USA) have been used in this study [20].

Apparatus

(a) Mixing Equipment: Hosokawa Micron Powder Systems Mikro Bantam Hammer and Screen Mill.

(b) Equipment for Microtracers recovery and counting.

- Rotary Detector ${ }^{\mathrm{TM}}$ magnetic separator;

- Scales technical WLC 0.2 / C / 1 (Radwag, Poland)

-Spray bottle containing 50\% ethanol solution.

Tracer Recovery and Counting

Upon receipt at Kormotech., the test items were individually weighed, and tracer particles were recovered and counted. Ferromagnetic particles of Microtracers Fseries were isolated from the six feed materials using a Rotary Detector magnetic separator. Recovered tracers were transferred from the small filter paper placed on the rotating magnet of the Rotary Detector to the surface of large filter paper $(18 \mathrm{~cm}$ in diameter) wetted with $50 \%$ ethanol solution to dissolve the dyes from the tracer and yield colored spots. Individual tracer particles formed colored spots on the filter papers, which were dried and the spots counted manually or by scanning to a computer and automatically counting according to a program developed by Micro-Tracers, Inc. and posted on their website [21]. 


\section{Results and discussion}

Summary information, including Tracer Recovery, Mean, Standard deviation, Coefficient of variation $(\%)$, Coefficient of variation-Poisson (\%), Chi-Square, Probability (\%) is presented in Table 1 for two different batches of Optimeal ${ }^{\mathrm{TM}}$ pet food. Both batches were prepared on the same mixing equipment with using two different Microtracers F-Series, both with an average particle count about 25 per $1 \mathrm{mg}$ The main differences between these batches was the time of mixing : 3 min for batch with results presented in Table 1 and $4 \mathrm{~min}$ for batch with results presented in Table 2 .

Table 1 - Experimental results on evaluating the quality of mixing with using Microtracer F-Blue \#1, Sample Assayed $-150 \mathrm{~g}$, at loading of $20 \mathrm{~g}$ of Tracer/Metric Ton of Optimeal ${ }^{T M}$ pet food. Time of mixing 3 min.

\begin{tabular}{|c|c|c|c|c|c|}
\hline \multicolumn{4}{|c|}{$\begin{array}{l}\text { Number of Samples } \\
\text { Analyzed, } 20\end{array}$} & Tracer Recovery & 96,27 \\
\hline 99 & 61 & 64 & 79 & Mean & 72,20 \\
\hline 91 & 61 & 82 & 64 & Standard deviation & 11,44 \\
\hline 56 & 84 & 63 & 68 & $\begin{array}{l}\text { Coefficient of } \\
\text { variation }(\%)\end{array}$ & 15,84 \\
\hline 70 & 77 & 71 & 87 & $\begin{array}{l}\text { Coefficient of } \\
\text { variation-Poisson (\%) }\end{array}$ & 11,77 \\
\hline 66 & 66 & 65 & 70 & Chi-Square & 34,42 \\
\hline \multicolumn{5}{|c|}{ Probability $(\%)$} & 1,12 \\
\hline \multicolumn{6}{|c|}{$\begin{array}{l}\text { Conclusion: A Chance Probability between } 1-5 \% \\
\text { evidences a marginal mix for the blue tracer }\end{array}$} \\
\hline
\end{tabular}

Table 2 - Experimental results on evaluating the quality of mixing with using Microtracer F-Red \#40, Sample Assayed $-150 \mathrm{~g}$, at loading of $20 \mathrm{~g}$ of Tracer/Metric Ton of Optimeal ${ }^{T M}$ pet food. Time of mixing 4 min.

\begin{tabular}{|c|c|c|c|c|c|}
\hline \multicolumn{4}{|c|}{$\begin{array}{c}\text { Number of Samples } \\
\text { Analyzed, } 20\end{array}$} & Tracer Recovery & 105,80 \\
\hline 78 & 71 & 83 & 101 & Mean & 79,35 \\
\hline 82 & 60 & 68 & 63 & Standard deviation & 10,85 \\
\hline 76 & 80 & 94 & 69 & $\begin{array}{l}\text { Coefficient of } \\
\text { variation }(\%)\end{array}$ & 13,67 \\
\hline 75 & 100 & 83 & 82 & $\begin{array}{l}\text { Coefficient of vari- } \\
\text { ation-Poisson }(\%)\end{array}$ & 11,23 \\
\hline 88 & 77 & 82 & 75 & Chi-Square & 28,19 \\
\hline \multicolumn{5}{|c|}{ Probability (\%) } & 5,93 \\
\hline
\end{tabular}

From the content of Tables 1 and 2 that summarize the results of calculations and conclusions obtained by the program of Micro-Tracers Inc [20], it can be seen that the found number of MT particles in 20 analyzed samples turns out to be rather close in value to the average number of particles: 72 (Table 1) or 79 (Table 2). It is obvious as well that the values of the coefficient of variation provide some evidence that the uniformity of mix for batch after $4 \mathrm{~min}$ of mixing $(\mathrm{CV} \sim 13.7$
$\%)$ is higher than for batch after 3 min of mixing (CV $15.8 \%$ ).

This conclusion is in a good correlation with results of evaluating the quality of mixing according to the method developed by Micro-Tracers Inc [21]. It is known that in counting particles as evidence of mixing results are defined by the applicable Poisson statistics, currently accepted by majority of statisticians [ 9, 18, 22]. The critical property of the Poisson statistics is that a count will be defined with a standard deviation equal to its square root. If one counts 400 particles or in the case of Microtracers colored spots, and one had no analytical data and analyzed an infinite number of samples and mixing was "perfect", it is expected to obtain a standard deviation of 20 and a CV then of $20 / 400$ or $5 \%$. Obviously, the larger amount of counts the lower value of CV is expected (Table 3 ).

Table 3 - Correlation between the counts and values of $C V$ expected from applying Poisson statistics

\begin{tabular}{||l||c||}
\hline \hline Counts & $\begin{array}{c}\text { The values of CV expected from applying } \\
\text { Poisson statistics \% }\end{array}$ \\
\hline \hline 100 & 10,00 \\
\hline \hline 400 & 5,00 \\
\hline 800 & 3,54 \\
\hline
\end{tabular}

As it is clear from Table 3 that at count of 100 , for example, the expected value of $\mathrm{CV}$ is around $10 \%$. Considering as example the mean value of 79,35 (Table 3), it is easy to calculate the expected value of CV from applying Poisson statistics :

$(79,35)^{1 / 2}=8,91$ and $\mathrm{CV}=(8,91 / 79,35) \times 100=11.23 \%$.

However, the experimental data presented in $\mathrm{Ta}$ ble 2 show that $\mathrm{CV}=13,67 \%$. Therefore, the question becomes is the excesss $\mathrm{CV}$ is random noise or statistically significant. For this, the Chi-squared calculation should be applied which yield a Chance Probability (P). If we find a Chance Probability greater than $5 \%$, we judge the data could reasonably have come from a Complete Mix and we accept it as evidencing such. If we get a Chance Probability of between $1 \%$ and $5 \%$ is is "Probably statistically significant" and the mix is judged "Probably Incomplete", if the Chance Probability is less than $1 \%$ this is considered a statistically significant deviation and the mix is judged Incomplete.

This approach is in complete agreement with published document [9] GMP+ Good Manufacturing Practices - Certifications schemes describing using ferromagnetic Microtracers to evaluate animal feed uniformity. Results of $P \leq 0.01$ reflect insufficient uniformity, results of $P \geq 0.05$ reflect good uniformity, and results of $0.01 \leq$ $P \leq 0.05$ suggest marginal uniformity, which may be suspect, and further investigation is warranted [9].

Thus, the results shown in Table 1 should be attributed to the case of marginal $\operatorname{mix}(\mathrm{P}=1,12 \%$, i.e. 0.01 $\leq P \leq 0.05$ ) and the results shown in Table 5 should be attributed to the case of complete mix $(\mathrm{P}=5,93 \%$, i.e. $P \geq 0.05$ ).

Numerous studies conducted in the USA, Serbia, Poland, Ireland, Italy, Russia and other countries show 
the high efficiency and speed of using ferromagnetic Microtracers to assess the uniformity of feed [12-16].

Their use is justified for solving specific problems, which include:

1. Comparison of the mixers based on the study of the efficiency of distribution of the Microtracer in them over the mixing composition;

2. Identification of changes in the technical characteristics of the mixer during operation over time,

3. Identification of changes in the composition or physical properties of the mixture on the distribution of the Microtracer in it.

It is important to point out that Microtracer should be added to the feed not by itself, but as a part of the mix with other conventional components of the feed. The amount of such a mixture in the studied feed should be similar to the amount of the component, which, in accordance with the formulation, is introduced into the feed in a minimum dose. The introduction of the Microtracer takes place in the same place as the introduction of other microcomponents of the feed. Then the results of the study will confirm the existing dosing and mixing procedures in the production of finished products.

\section{Conclusion}

Ferromagnetic Microtracers, such as Microtracers F-series can be used as an effective tool for determination of the quality of mixing processes and can be useful at the time of purchasing mixing equipment and for evaluation of every production run.

The detailed knowledge of the time and speed of mixing is especially important because the manufacturers of pet food waste energy, labor and capital when they run mixing too long. Besides, an excessive mixing may also lead to degradation such valuable components of pet food as vitamins, enzymes and medications. The required information can be obtained using Microtracers that are widely used in 66 countries of the world, not only for evaluation of mixing performance, but also for crosscontamination determination and for coding microingredients in pet food and animal feed.

ACKNOWLEDGMENTS We are grateful to Sergey Dorda, a technologist at Kormotech, for helping us to conduct experiments to evaluate the uniformity of pet food manufacturing.

\section{REFERENCES}

1. Sirenko S.O. Market research and demand generation in the pet food market / S.O. Sirenko // Economics and Management of Enterprises. - 2019. - Issue 32. - P.213-217.

2. Khimich M.S. Analysis of the domestic feed market for non-productive animals (dogs and cats) / M.S. Khimich, I.I. Beloshitskaya // Scientific Bulletin of Lviv National University of Veterinary Medicine and Biotechnology. Hedgehog. - 2015. - Vol. 17, No. 1 (2). - P. 302-307.

3. Egorov B.V. Development of technology for the production of wet compound food for pets - cats / B.V Egorov, T.V Bordun // Scientific works [Odessa National Academy of Food Technologies]. - 2009. - V. 36 (1). - P. 38-43.

4. Egorov V.B. Analysis of technological lines for the production of animal feed as management objects / V. B. Egorov// Grain Products and Mixed Fodder's. - 2013. - No. 3 (51). - S. 47-54.

5. Khabibullin, $R \&$ Khrundin, $D \&$ Sabirzyanova, $R \&$ Ezhkova, G. (2019). Poultry by-products as a basis of combined meat and vegetable feed for domestic animals. IOP Conference Series: Earth and Environmental Science. 337. 012003. 10.1088/1755-1315/337/1/012003.

6. European Union (2002). Regulation (EC) No 1774/2002 of the European Parliament and of the Council of 3 October 2002 laying down health rules concerning animal by-products not intended for human consumption. Official Journal L 273, p.1, 10.10.2002. Official Journal of the European Communities L 273 Volume 4510 October 2002. 95 p.

7. 7.Popenkova D.K. The dynamics of the world market of consumer goods (for example, pet food) / D.K. Popenkova // University Herald State University of Management (Moscow) 2013. - V. 19. - S. 195-201.

8. Herrman T and Behnke K. Feed Manufacturing - Testing mixer performance. In: Bul. MF-1172 Revised, Kansas St. University Cooperative Extension Service, 1994, Manhattan, KS

9. Control of residues GMP + BA 2 Version EN: 1 April 2019 GMP + Feed Certification scheme

10. Buben O.R.KORMOTECH - The best food killer for homemade creatures in Ukraine / O.R.Buben, G.M. Zholinska // International commerce on the current market: position, security, security in the context of the European Integration: Zbirnik Materials All-Ukrainian Scientific and Practical Conference (m. Lv. 16 april). 2019. - C.16-21.

11. Thiex N. Evaluation of the Use of Microtracers ${ }^{\mathrm{TM}}$ in a Proficiency Testing Program / N Thiex et all. // JAOAC Int. 2019 May 1;102(3):767-775. doi: 10.5740/jaoacint.18-0354. Epub 2019 Jan 16.

12. Barashkov N.N. Ferromagnetic microtracers as indicators of the uniformity of feed quality for livestock and poultry farming / N.N. Barashkov, P.V. Pisarenko, V.Yu. Krikunova, T.V. Sakhno, O.A. Krikunov // Grain Products and Mixed Fodder's. - 2016 .-- Vol.63, N I.3. - C. 34-40.

13. Sakhno T.V. The application of statistical methods of quality management by GMP + standards using ferromagnetic microtracers / T.V.Sakhno, P.V. Pisarenko, I.V.Korotkova, O. M.Omelian, N. N. Barashkov // Grain Products and Mixed Fodder's. - 2018 .-- V.18. - N 3. - R.39-44.

14. Pisarenko P.V. The use of ferromagnetic microtracers as indicators of the quality of uniformity of feed in agriculture / P.V. Pisarenko, V.E. Krikunova, T.V. Sakhno, O.A. Krikunov, N.N. Barashkov / Bulletin of the Kurgan State Agricultural Academy. - 2016. - T. No. 4. - S.-50-54.

15. Djuragic O. Evaluation of homogeneity in feed by method of microtracer ${ }^{\circledR} /$ O. Djuragic, J. Levic, S.Sredanovic, L Lević //Archiva Zootechnica. - 2009. - V.12(4). - P. 85-91.

16. Eisenberg S. and Eisenberg D. Particle Size and Mixing Problems for Aquatic Feeds // Feed Manufacturing, Technology IV, AFIA, 1994. P. 498-499

17. Eisenberg D.A. MicroTracer(TM) F and their uses in assuring the quality of mixed formula feeds / D.A Eisenberg // Adv. Feed Technol. - 1992. - 7. - P. 78-85.

18. Eisenberg D. Mix with confidence // International Milling Flour and Feed. - 1994. 188. - P. 31-33. 
19. Sakhno T. The investigation of segregation of ferromagnetic microtracers from premixes: results of testing in model conditions and during of delivery and storage /T.Sakhno, I. Korotkova, N.Barashkov // Grain Products and Mixed Fodder's. - 2017. - V. 17. - N 2 . - P.28-33.

20. https://microtracers.com/product/f-tracers/

21. Barashkov N. Ferromagnetic microtracers and their use in feed applications senberg / N.Barashkov, D.Eisenberg, S.Eisenberg, J. Mohnke // XII Int. Feed Technol. Symp. Novi Sad, 2008.

22. Bernotas D. On the Use of Particulate Distributions for Determining Degree of Homogeneity in a Feed Mixture" Letter and Article, April 2012. https://microtracers.com/wp-content/uploads/2017/05/B-1-Statistical-Verification-ofMicro-Tracers-Methods-2012-4-26-12-ZE.pdf

\title{
УДК 636.085.32
}

T. Сахно, д-р хім. наук, професор, E-mail: sakhno2001@gmail.com Полтавська державна аграрна академія, вул. Сковороди 1/3, м. Полтава, 36003, Украӥна А. Семенов, канд. фіз.мат. наук, доцент, E-mail: asemen2015@gmail.com Полтавський університет економіки та торгівлі, вул. Коваля, 3, м. Полтава, 36014, Україна Н. Барашков, д-р хім. наук, професор, E-mail: nikolay@microtracers.com Micro-Tracers, Inc, 1370 Van Dyke Ave, Сан-Франциско, Каліфорнія, 94124, США

\section{ОЦІНКА ЯКОСТІ ГОМОГЕННОСТІ КОРМІВ ДЛЯ ДОМАШНІХ ТВАРИН 3 ВИКОРИСТАННЯМ ФЕРРОМАГНІТНИХ МІКРОТРЕЙСЕРІВ}

\begin{abstract}
Анотація
Отримання високогомогенних сумішей с актуальним завданням в багатьох сферах виробництва кормів, так як воно пов 'язане з необхідністю рівномірного розподілу особливо важливих і иінних компонентів. Від ступеня однорідності кінцевого продукту залежить ефективність його дії та безпечність при використанні. Тому одним із пріоритетних завдань виробників кормових сумішей - це підтверджена доказова база якості їх продукиії, яка полягає в точності дозування та однорідності змімування всіх компонентів.

У даній роботі для оиінки якості однорідності кормової суміші пропонується використання нетрадиційних маркерів, таких як феромагнітні мікротрейсери. Автори представили кількісні результати ідентифікачї мікротрейсерів у двох пробах по 20 зразків кожна кормів для домашніх тварин, виготовлених ТОВ «Кормотех» з використанням обертального детектора компанії Micro-Tracers Inc (Сан-Франциско, Коліфорнія). Показано, щчо аналіз 150 г зразків на рівні додавання мікротрейсерів 20 г на метричну тону корму для домашніх тварин дозволило отримати магнітне дослідження кількості феромагнітних частинок від 61 до 101 шт., щуо було достатнім для застосування статистики Пуассона та Х-квадрату. Отримані результати двох тестів, проведених з різним часом перемішування, інтерпретували відповідно до вимог стандарту GMP + ВА2. Визначено, ше змішування протягом 3 хв призводить до граничного змішування із розрахунковим значенням ймовірності 1,12\%, а тривале перемішування протягом 4 хв призводить до повного змішування із розрахунковим значенням ймовірності $5,93 \%$.

Застосування феромагнітних мікротрейсерів для оцінки однорідності кормів є виправданим для вирішення наступних завдань: порівняння змішувачів між собою; виявлення з плином часу технічних змін в характеристиках змішувача при експлуатаиії; виявлення змін складу або фізичних властивостей кормової суміші при розподілі в ній індикатору. Крім того, використовуючи мікротрейсери можна швидко визначити якість змішувального обладнання при його придбанні.

Ключові слова: змішування, комбікорм, якість кормів, мікротрейсери, маркери, корм для домашніх тварин, обертовий детектор
\end{abstract}

\section{ЛІТЕРАТУРА}

1. Сіренко С.О. Вивчення ринку і формування попиту на ринку кормів для домашніх тварин / С.О. Сіренко // Економіка та управління підприємствами. - 2019. - Випуск 32. - С.213-217. [Електронний ресурс]. - Режим docmyny: http://www.market-infr.od.ua/journals/2019/32_2019_ukr/33.pdf

2. Хімич М. С. Аналіз вітчизняного ринку кормів для непродуктивних тварин (собак та кімок) / М. С. Хімич, I. I. Білошицька // Науковий вісник Львівського національного університету ветеринарної медицини та біотехнологій ім. Гжицького. - 2015. - T. 17, № 1(2). - С. 302-307. - Режим доступу: http://nbuv.gov.ua/UJRN/nvlnu_2015_17_1(2)_62

3. Сгоров Б. В. Розробка технології виробництва вологих комбікормів для домашніх тварин - кімок / Б. В. Єгоров, Т. В. Бордун // Наукові прачі [Одеської начіональної академії харчових технологій]. - 2009. - Вип. 36(1). - C. 38-43. - Режим достуny: http://nbuv.gov.ua/UJRN/Np_2009_36(1)_12.

4. Егоров В.Б. Анализ технологических линий производства комбикормов как объектов управления / В.Б. Егоров // Зернові продукти і комбікорми. - 2013. - № 3 (51). - C.47-54.

5. Khabibullin, $R \&$ Khrundin, $D \&$ Sabirzyanova, $R \&$ Ezhkova, G. (2019). Poultry by-products as a basis of combined meat and vegetable feed for domestic animals. IOP Conference Series: Earth and Environmental Science. 337. 012003. 10.1088/1755-1315/337/1/012003. DOI: 10.1088/1755-1315/337/1/012003 Published 1 November $2019 \cdot$ Published under licence by IOP Publishing Ltd IOP Conference Series: Earth and Environmental Science, Volume 337, P. 012003. Efficient waste treatment - 2018 13-14 December 2018, Congress Center of Peter the Great, St. Petersburg Polytechnic University IOP Conference Series: Earth and Environmental Science. IOP Publishing - 2019. 2019/11/16. - V.337. - P.012003. 
6. Regulation No. 1774/2002 of the European Parliament and of the Council of 3 October 2002 laying down of health rules concerning animal by-products not intended for human consumption. Official Journal of the European parliament L273/1. November 2002.

7. Попенкова Д.К. Динамика развития мирового рынка товаров народного потребления (на примере кормов для домашних животных) / Д.К. Попенкова //Вестник университета Государственный университет управления (Москва) 2013. - T.19. - C. 195-201. eLIBRARY ID: 21095085 https://elibrary.ru/item.asp?id=21095085

8. Herrman T and Behnke K. Feed Manufacturing - Testing mixer performance. In: Bul. MF-1172 Revised, Kansas St. University Cooperative Extension Service, 1994, Manhattan, KS.

9. Control of residues GMP+BA 2 Version EN: 1 April 2019 GMP+ Feed Certification scheme

10. Бубен О.Р. КОRМОТЕСН - Найбільший виробник кормів для домашніх тварин в Украйні / О.Р.Бубен, Г.М. Жолинська // Вітчизняні товари на сучасному ринку: позиціонування, якість, безпечність у контексті Європейської інтеграчї: Збірник матеріалів Всеукраӥнської науково-практичної конферениї̈ (м. Львів, 16 квітня 2019 р.) - Львів: ЛIЕТ, 2019. 179 с.С.16-21.

11. Thiex N. Evaluation of the Use of Microtracers ${ }^{\mathrm{TM}}$ in a Proficiency Testing Program / N Thiex et all. // JAOAC Int. 2019 May 1;102(3):767-775. DOI 10.5740/jaoacint.18-0354. Epub 2019 Jan 16.

12. Барашков Н.Н. Ферромагнитные микротрейсеры как индикаторы качества однородности комбикормов для живодноводства и птицеводства / Н.Н.Барашков, П.В.Писаренко, В.Ю.Крикунова, Т.В.Сахно, О.А.Крикунов // Зернові продукти і комбікорми. - 2016. - Vol.63, N I.3. - C.34-40. DOI 10.15673/gpmf.v63i3.219

13. Sakhno T.V. The application of statistical methods of quality management by GMP+ standards using ferromagnetic microtracers / Sakhno T.V., Pisarenko P.V., Korotkova I.V., Omelian O. M., Barashkov N. N. // Grain Products and Mixed Fodder's. - 2018. - V.18. - N 3. - P.39-44. DOI https://doi.org/10.15673/gpmf.v18i3.1078

14. Писаренко П.В. Применение ферромагнитных микротрейсеров как индикаторов качества однородности комбикормов в сельском хозяйстве / П.В. Писаренко, В.Е.Крикунова, Т.В.Сахно, О.А.Крикунов, Н.Н. Барашков / Вестник Курганской ГСXА. - 2016. - T. №4. - C.-50-54. eLIBRARY ID: 27682256

15. Djuragic O. Evaluation of homogeneity in feed by method of microtracer ${ }^{\circledR} /$ O. Djuragic, J. Levic, S.Sredanovic, L Lević //Archiva Zootechnica. - 2009. - V.12(4). - P. 85-91.

16. Eisenberg S. and Eisenberg D. Particle Size and Mixing Problems for Aquatic Feeds // Feed Manufacturing, Technology IV, AFIA, 1994. P. 498-499.

17. Eisenberg D.A. MicroTracer(TM) $F$ and their uses in assuring the quality of mixed formula feeds / D.A Eisenberg // Adv. Feed Technol. - 1992. - 7. - P. 78-85.

18. Eisenberg D. Mix with confidence // International Milling Flour and Feed. - 1994. 188. - P. 31-33.

19. Sakhno T. The investigation of segregation of ferromagnetic microtracers from premixes: results of testing in model conditions and during of delivery and storage /T.Sakhno, I. Korotkova, N.Barashkov // Grain Products and Mixed Fodder's. - 2017. - V. 17. - N2 - - P.28-33.

20. [Електронний ресурс]. - Режим доступy: https://microtracers.com/product/f-tracers/

21. Barashkov N. Ferromagnetic microtracers and their use in feed applications senberg / N.Barashkov, D.Eisenberg, S.Eisenberg, J. Mohnke // XII Int. Feed Technol. Symp. Novi Sad, 2008.

22. Bernotas D. On the Use of Particulate Distributions for Determining Degree of Homogeneity in a Feed Mixture" Letter and Article, April 2012. https://microtracers.com/wp-content/uploads/2017/05/B-1-Statistical-Verification-ofMicro-Tracers-Methods-2012-4-26-12-ZE.pdf

\section{Received 24.03.2020 \\ Reviewed 17.04.2020}

\section{Revised $\quad 07.05 .2020$ Approved 10.06.2020}

\section{Cite as Vancouver Citation Style}

Sakhno T., Semenov A., Barashkov N. Assessing the quality of homogeneity of pet food using ferromagnetic microtracers. Grain Products and Mixed Fodder's, 2020; 20 (2, 78): 32-37.

DOI: https://doi.org

\section{Cite as State Standard of Ukraine 8302:2015}

Assessing the quality of homogeneity of pet food using ferromagnetic microtracers / Sakhno T. et al. // Grain Products and Mixed Fodder's. 2020. Vol. 20, Issue 2 (78). P. 32-37.

DOI: https://doi.org

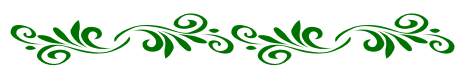

